\title{
A DEEP DIVE INTO THE CHRONIC AIR POLLUTION REALITY IN BAIA MARE: PART II: AIR QUALITY EVOLUTION BETWEEN 1995 - 2006
}

\author{
Valentina-Mariana Manoiu ${ }^{1 \star}$, Razvan Madalin Spiridon ${ }^{2}$, Marina Antonescu ${ }^{3}$ \\ ${ }^{1}$ Assoc.Prof.Dr, Faculty of Geography, University of Bucharest, ROMANIA, \\ valentina.mariana.manoiu@gmail.com \\ ²Environmental Consultant, Auditeco GES, Bucharest, ROMANIA, razvanspiridon@gmail.com \\ ${ }^{3}$ Master Student, Faculty of Geography, University of Bucharest, ROMANIA, \\ marina_antonescu@yahoo.com \\ ${ }^{*}$ Corresponding author
}

\begin{abstract}
Baia Mare, the former mining and metallurgical industry capital of Romania, is one of the most problematic areas in the country in terms of historical pollution and its consequences. The present paper, as the second part of a complex three-piece study, aims to analyze the air quality evolution in Baia Mare between 1995 and 2006. In the previous piece, the first of this series, we provided an overview of the sources of historical air pollution in Baia Mare. In the third and final scientific paper, we will analyze the effects of this chronic pollution on human health. This article constitutes an analysis of the air quality in Baia Mare, representing a historical investigation of this important environmental issue in the city's area. Our work updates and expands the body of information provided by previous papers on the topic of environmental pollution in Baia Mare, its purpose being to highlight the chronic air pollution with sulphur dioxide, nitrogen dioxide, ammonia, suspended and sedimentary particulate matters, as well as heavy metals between 1995 and 2006. As a result of the above, it can be concluded that the air quality in Baia Mare in 1995-2006 was especially critical due to high concentrations of particulate matters presenting high lead and cadmium content, as well as high sulphur dioxide concentrations. These pollutants were generated by mining and metallurgical units (Remin, Phoenix/Cuprom and Romplumb Corporations), alongside other factors: tailing dumps and tailing ponds in the Baia Mare area, where the particulates were spread around by the air currents; industrial and residential heating equipments with solid fuel; road traffic, including road dust resuspension; mix-asphalt installations; woodworking etc. The calm weather conditions, unfavourable to the dispersion of pollutants in the Baia Mare area, have also contributed to the air quality deterioration. However, for the selected timeframe, the pollutant evolution tendency in the local atmosphere showed a decrease of the heavy metal and sulphur dioxide concentrations, which was a result of reduced productive activity for all the local heavy-polluters and not due to the investments aimed at improving urban air quality, which did not lead to any significant changes. Currently, Remin and Romplumb Corporations are insolvent and Cuprom Corporation is bankrupt.
\end{abstract}

Keywords: Baia Mare, historical pollution, air quality, sulphur dioxide, particulate matter, heavy metals 


\section{PURPOSE OF THE STUDY AND BACKGROUND}

The city of Baia Mare is an important urban centre in north-western Romania, located in the western part of Maramures County, on the middle course of the Sasar River, in an area known as the Baia Mare Depression. This former "capital" of the Romanian mining and metallurgical industry is one of the country's most problematic areas in terms of historical pollution and its consequences. In Baia Mare, pollution is chronic, with multiple sources. (Manoiu and Spiridon, 2017).

The present paper, the second part of a complex three-piece study, aims to analyze the evolution in air quality in Baia Mare, between 1995 and 2006. In the first part of the study we offered an overview of the historical air pollution sources in Baia Mare (Manoiu and Spiridon, 2017). In the third and final paper, we will analyze the effects of this chronic pollution on human health.

The present piece is a historical analysis of air quality evolution in Baia Mare. Our research enriches the body of information submitted by previous papers focused on the same topic of environmental pollution in Baia Mare, looking to highlight the chronic air pollution with sulphur dioxide, nitrogen dioxide, ammonia, suspended and sedimentary particulate matters, as well as heavy metals, between 1995 and 2006.

Baia Mare is found at $47^{\circ} 39^{\prime}-47^{\circ} 48^{\prime}$ northern latitude and $23^{\circ} 10^{\prime}-23^{\circ} 30^{\prime}$ western longitude. The city has an area of $235.73 \mathrm{~km}^{2}$ and a population of 123.738 inhabitants, according to the census conducted in 2011 (National Institute of Statistics, 2011). Baia Mare is known for its constant atmospheric calm which is unfavourable to the dispersion of pollutants and is one of the main causes for noxious gas accumulation in the area.

\section{AIR QUALITY EVOLUTION IN BAIA MARE BETWEEN 1995 AND 2006}

\subsection{General Overview}

The major air quality issues in the area were caused by industrial activities - Baia Mare is known as a town with a long-lasting mining and metallurgical tradition. The Maramures County industry had a significant contribution to Romania's production of lead, copper, gold and silver. At the same time, due to the nature of their activities, these industrial branches were known to be heavy polluters. Historical environmental pollution (including air pollution) in Baia Mare had three main sources: the National Company of Precious and Nonferrous Metals (NCPNM) - Remin Corporation; Cuprom Corporation; Romplumb Corporation (Manoiu and Spiridon, 2017). The pollutants emitted from the non-ferrous metallurgical units activities were sulphur dioxide $\left(\mathrm{SO}_{2}\right)$; suspended and sedimentary particulate matters containing lead $(\mathrm{Pb})$, cadmium $(\mathrm{Cd})$, copper $(\mathrm{Cu})$, arsenic (As) and other metals.

During the analyzed period, the air quality monitoring actions were carried out through manual sampling (Fig.1) and laboratory analysis, while keeping track of a series of specific indicators. In Baia Mare, the automatic air quality monitoring stations were only introduced on January $1^{\text {st }}, 2008$ (Maramures EPA, 19952006).

Between 1995 and 2006, the laboratory samples and their analysis focused on the following pollutants/indicators:

a). Sulphur dioxide $\left(\mathrm{SO}_{2}\right)$. In 1996, the samples for sulphur dioxide, nitrogen dioxide and ammonia were collected at 8 stations in Baia Mare, and between 1997 and 1999, at 7 stations. Starting with 2000, the air samples for individual sulphur dioxide analysis were collected at 7 stations. In 2001 and 2002, the number of sampling points and $\mathrm{SO}_{2}$ analysis was the same as in 2000. In 2003 and 2004, there were $6 \mathrm{SO}_{2}$ sample collection points, with one of them being put out of function temporarily. In 2005 and 2006, the sulphur dioxide samples were taken from 7 collection points (Maramures EPA, 1995-2006).

b). Nitrogen dioxide $\left(\mathrm{NO}_{2}\right)$ and ammonia $\left(\mathrm{NH}_{3}\right)$. Until 2000, air samples for $\mathrm{SO}_{2}, \mathrm{NO}_{2}$ and $\mathrm{NH}_{3}$ analysis were collected from the same 7 or 8 stations in Baia Mare. Since 2000, the analysis for $\mathrm{NO}_{2}$ and $\mathrm{NH}_{3}$ was run on samples collected at 2 stations. In 2001 and 2002 there was the same number of collection points as in 2000. In 2003 and 2004, the air samples for these two indicators were collected at a single station. In 2005 and 2006, once more, two collection points were used for the $\mathrm{NO}_{2}$ and $\mathrm{NH}_{3}$ samples (Maramures EPA, 19952006).

c). Suspended/particulate matter. In 1996, in Baia Mare, the samples for suspended/particulate matter and the accompanying heavy metals were collected at 3 stations, while between 1997 and 1999, 4 sampling points were used. From 2000 to 2004, the number of sampling points for suspension matter and associated heavy metals decreased to 3 , and 2 of them were located in industrial areas under the direct impact of pollution sources (sampling point no. 4, near Romplumb Corporation, and sampling point no. 16 near 
Phoenix/Cuprom Corporation); the third sampling point was located in a residential area (point no. 31, near Maramures Environmental Protection Agency-EPA). In 2005 and 2006, there were 3 sampling points (2 industrial sampling points, similar to the 2000-2004 setup and an urban sampling point, located near Maramures EPA), as well as an additional one for PM10 (particulate matter smaller or equal to $10 \mu \mathrm{m}$ ) (Maramures EPA, 1995-2006).

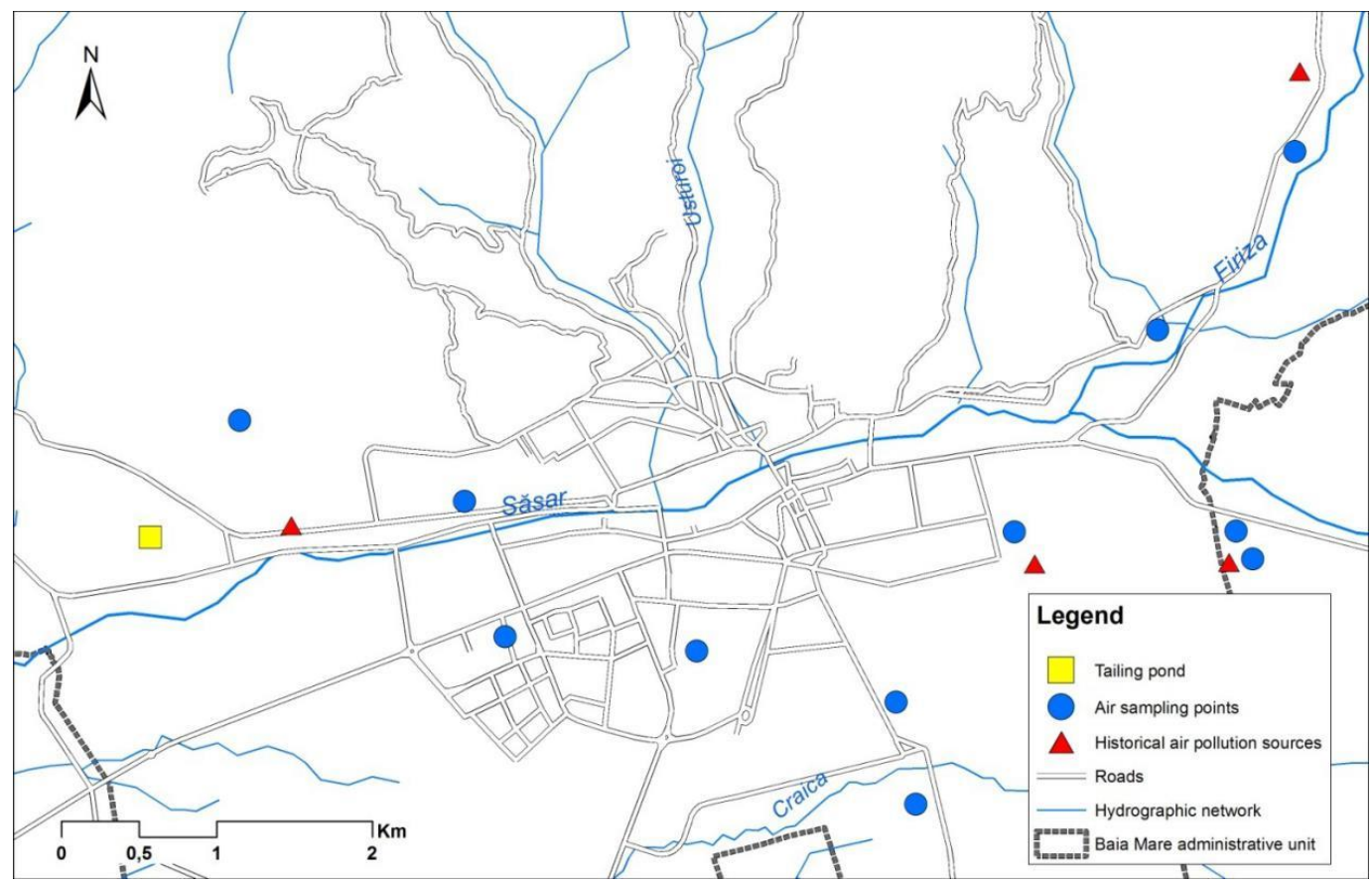

Fig.1. Baia Mare and its air sampling points and pollution sources in 2006

d). Sedimentary matter. In 1996, in Baia Mare, sedimentary matter samples were collected from 20-22 points, while only 7 were still used a year later in 1997. From 1998 to 2002, there were 8 sampling points and it was in 2000 that the heavy metals contained by these powders were identified. In 2003 and 2004, the samples were collected from 7 sampling points, and an additional one was introduced in 2005 (Maramures EPA, 1995-2006).

Between 1995 and 1999, all sample collection points for gaseous and solid pollutants were located in urban areas. From 2000 to 2006, two industrial sampling points located under the direct impact of industrial pollution sources were introduced (sampling point no. 4, near Romplumb Corporation and sampling point no. 16 near Phoenix/Cuprom Corporation); the other collection points were located in urban areas. Between 1995 and 2002, the pollutant concentration evolution analysis was based on the reference values provided in the Standard 12574/1987 - Standard regarding air quality conditions in protected areas. Between 2003 and 2006, the Order of the Water and Environmental Protection Ministry no. 592/2002 (introduced in 2003 and repealed in 2011) was consulted while analyzing the air quality evolution indicators (Maramures EPA, 19952006).

\subsection{Sulphur Dioxide Pollution $\left(\mathrm{SO}_{2}\right)$}

Between 1995 and 2006, according to the analysis of the $\mathrm{SO}_{2}$ indicator, there was a significant decrease in the $\mathrm{SO}_{2}$ pollution level (Fig.2), both in terms of exceeding the maximum admissible concentrations (MAC), as well as the average and maximum values recorded (Maramures EPA, 1995-2006). This is due to the cessation in 2000 of certain highly polluting production lines owned by Phoenix/Cuprom Corporation, which up to 2000 was the main $\mathrm{SO}_{2}$ pollution source in Baia Mare.

The evolution analysis for the $\mathrm{SO}_{2}$ indicator points to a significant decrease. The maximum annual average was recorded in $1995\left(186 \mu \mathrm{g} / \mathrm{m}^{3}\right)$ and the minimum $\left(14 \mu \mathrm{g} / \mathrm{m}^{3}\right)$ was recorded in 2005 and 2006. The annual daily maximum recorded in Baia Mare area was between $5723 \mu \mathrm{g} / \mathrm{m}^{3}$ (almost 23 times the daily MAC value) in 1995 and $146 \mu \mathrm{g} / \mathrm{m}^{3}$ in 2002. In 1995, Cuprom Corporation introduced a 350m high gas dispersion chimney. Although not considered an ecological method, the chimney did contribute to the gases' dispersion, including $\mathrm{SO}_{2}$, as concentrations began decreasing significantly in the coming years (Maramures EPA, 19952006). 


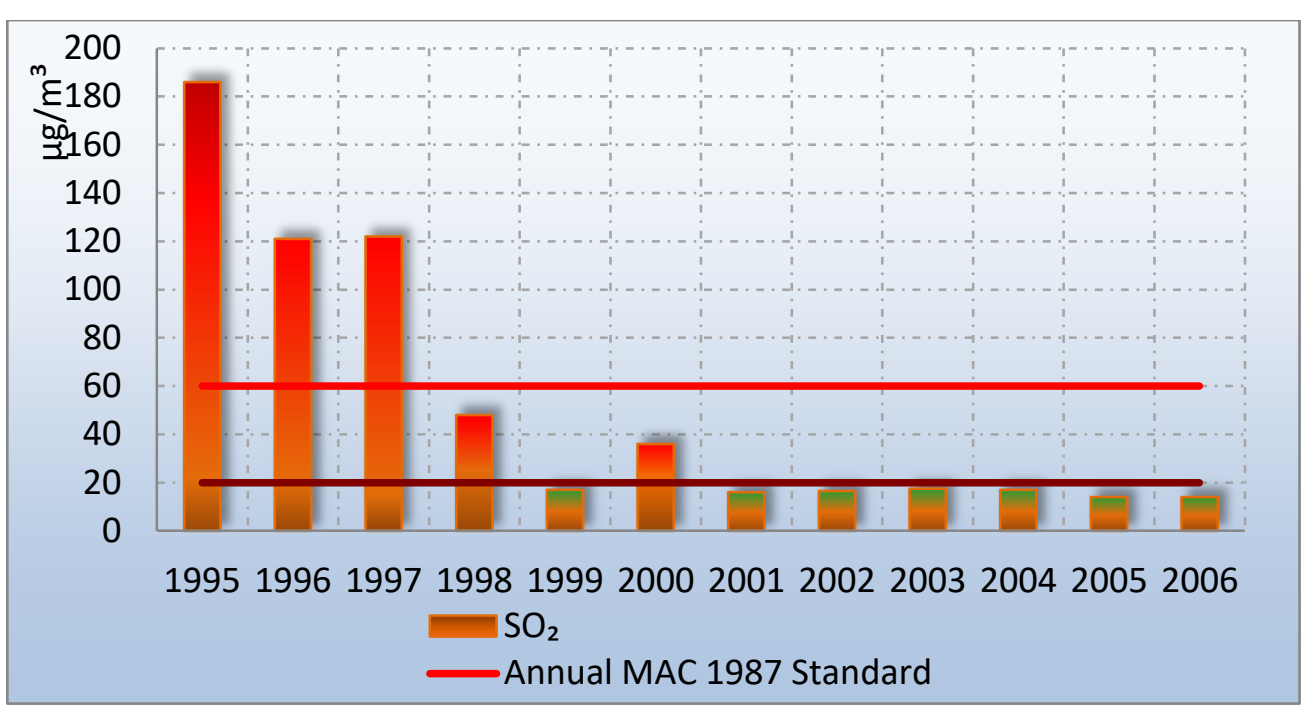

Fig.2. The annual average values of sulphur dioxide concentrations between 1995 and 2006

Between 1995 and 2002, sulphur dioxide concentration evolution analysis was conducted in relation to the reference values provided in the Standard 12574/1987 regarding air quality conditions in protected areas $\left(\mathrm{MAC} / 24\right.$ hours $=250 \mu \mathrm{g} / \mathrm{m}^{3} ; \mathrm{MAC} /$ year $\left.=60 \mu \mathrm{g} / \mathrm{m}^{3}\right)$. Between 2003 and 2006, for the same task, the analysis used the reference values of the 592/2002 Order, released by the Waters and Environmental Protection Ministry $\left(\mathrm{MAC} / 24\right.$ hours $=125 \mu \mathrm{g} / \mathrm{m}^{3} ;$ MAC/year $\left.=20 \mu \mathrm{g} / \mathrm{m}^{3}\right)$.

Therefore, according to the old indicator, the annual MAC was exceeded in 1995 more than 3 times and twice in 1996 and 1997. Still, between 1998 and 2002, the annual MAC did not record any exceedances. As far as the new provisions are concerned, the annual MAC was not exceeded between 2003 and 2006, with a constant annual average concentration of $14 \mu \mathrm{g} / \mathrm{m}^{3}$ (Maramures EPA, 1995-2006).

The annual frequency of daily MAC exceedance dropped from a maximum of $19 \%$ in 1995 to $0 \%$ in 2002 , which was the first year that did not record any daily MAC exceedance. In 2003 and 2005, the exceedance frequency was also 0\%, while for 2004 and 2006, the reports filed by the Maramures EPA (Maramures EPA, 1995-2006) did not specify the values corresponding to the daily MAC exceedance frequency. However, it is mentioned that in 2004 the limit value for a 24-hour mediation time (LV/24 hours $\left.=125 \mu \mathrm{g} / \mathrm{m}^{3}\right)$ was exceeded 8 times, and the maximum daily values were between 29 and $202 \mu \mathrm{g} / \mathrm{m}^{3}$.

In 2006, monitoring the $\mathrm{SO}_{2}$ concentration levels was done using 7 sampling points around Baia Mare. The analysis for this pollutant was conducted according to the Standard 10194/1989 (indicative measurement, not automatic). That year, there were two exceedances of the limit value for a 24 -hour mediation time (LV/24 hours $=125 \mu \mathrm{g} / \mathrm{m}^{3}$ ). The daily maximum values in the measurement points ranged from $27 \mu \mathrm{gg} / \mathrm{m}^{3}$ to 134 $\mu \mathrm{g} / \mathrm{m}^{3}$, while the annual averages for the 7 sampling points varied between 5 and $29 \mu \mathrm{g} / \mathrm{m}^{3}$. The annual average concentration was $14 \mu \mathrm{g} / \mathrm{m}^{3}$ (Maramures EPA, 1995-2006).

After 2000, the main $\mathrm{SO}_{2}$ pollution source was Romplumb Corporation, which released into the atmosphere all gases resulting from the various ongoing technological processes. Alongside this source, local traffic was also responsible for $\mathrm{SO}_{2}$ air pollution, but to a lesser degree.

\subsection{Nitrogen Dioxide $\left(\mathrm{NO}_{2}\right)$ And Ammonia $\left(\mathrm{NH}_{3}\right)$ Pollution}

For the nitrogen dioxide $\left(\mathrm{NO}_{2}\right)$ indicator, tests were run on daily samples starting with 2000 , with two sampling points close to Baia Mare (Maramures EPA, 1995-2006). The annual average values are listed in the table1.

Between 2000 and 2002, the nitrogen dioxide concentration evolution analysis was carried out using the reference values listed in the Standard $12574 / 1987$ - Standard on air quality conditions in protected areas $\left(\mathrm{MAC} / 24\right.$ hours $=100 \mu \mathrm{g} / \mathrm{m}^{3} ;$ MAC/year $\left.=40 \mu \mathrm{g} / \mathrm{m}^{3}\right)$. Between 2003 and 2006, the analysis followed the reference values of the Order no. 592/2002 released by the Waters and Environment Protection Ministry (no daily MAC specified; MAC/year $=40 \mu \mathrm{g} / \mathrm{m}^{3}$, identical to the 1987 Standard). 
IJASOS- International E-Journal of Advances in Social Sciences, Vol. III, Issue 9, December 2017

Tabel 1. The annual average values for $\mathrm{NO}_{2}$ concentrations between 2000 and 2006 (Source: Maramures EPA, 1995-2006)

\begin{tabular}{|l|l|l|l|l|l|l|l|l|}
\hline Year & $\mathbf{2 0 0 0}$ & $\mathbf{2 0 0 1}$ & $\mathbf{2 0 0 2}$ & $\mathbf{2 0 0 3}$ & $\mathbf{2 0 0 4}$ & $\mathbf{2 0 0 5}$ & $\mathbf{2 0 0 6}$ & MAC \\
\hline $\begin{array}{l}\text { Value } \\
\left(\mu \mathrm{g} / \mathrm{m}^{3}\right)\end{array}$ & 20,37 & 25,4 & 20,61 & 11,78 & 10,76 & 14 & 13 & 40 \\
\hline
\end{tabular}

There was no exceedance of the annual MAC signalled for this indicator between 2000 and 2006 (Maramures EPA, 1995-2006), which points to the conclusion that nitrogen dioxide did not contribute significantly to the pollution in the area. Although in 2000 records show an exceedance frequency of MAC/24hours of $4 \%$ and a daily maximum value of $268 \mu \mathrm{g} / \mathrm{m}^{3}(2,7$ times more than the daily MAC, caused by the metallurgical industry), between 2001 and 2004 such occurrences disappeared. In 2005, the daily maximum value was $76 \mu \mathrm{g} / \mathrm{m}^{3}$, caused by the metallurgical industry and traffic. The main nitrogen oxide emission sources in Baia Mare were and still are road traffic, local industry (burning from technological processes) and combustion in non-industrial installations (thermal power plants for heat and domestic hot water production).

In 2006, the average concentration was $13 \mu \mathrm{g} / \mathrm{m}^{3}$ (lower than in the previous year), with a daily maximum value of $40 \mathrm{\mu g} / \mathrm{m}^{3}$ (Maramures EPA, 1995-2006). The numbers were recorded using indicative measurements over a 24-hour mediation period.

For the ammonia indicator $\left(\mathrm{NH}_{3}\right)$, the daily sample analysis started in 2000 as well, establishing alongside the nitrogen dioxide indicator $\left(\mathrm{NO}_{2}\right)$ two monitoring points for the concentration levels (Maramures EPA, 1995-2006). The ammonia annual average concentration is shown in the table 2.

Table 2. The annual average $\mathrm{NH}_{3}$ concentration values between 2000 and 2006 (Source: Maramures EPA)

\begin{tabular}{|l|l|l|l|l|l|l|l|l|}
\hline Year & $\mathbf{2 0 0 0}$ & $\mathbf{2 0 0 1}$ & $\mathbf{2 0 0 2}$ & $\mathbf{2 0 0 3}$ & $\mathbf{2 0 0 4}$ & $\mathbf{2 0 0 5}$ & $\mathbf{2 0 0 6}$ & MAC \\
\hline $\begin{array}{l}\text { Value } \\
\left(\mu \mathrm{g} / \mathrm{m}^{3}\right)\end{array}$ & 27,85 & 16,51 & 10,021 & 4,00 & 2,37 & 13 & 18 & 100 \\
\hline
\end{tabular}

It should be noted that the $12574 / 1987$ Standard did not provide a $\mathrm{NH}_{3}$ annual MAC, but only a daily 100 $\mathrm{\mu g} / \mathrm{m}^{3}$ MAC, while the 592/2002 Order did not make any reference to this indicator. Therefore, for the analysis, the reporting was made based on the limits imposed by the 12574/1987 Standard. Up to 2004, the data provided by Maramures EPA pointed to a continuous decrease of ammonia concentrations in the Baia Mare area, which then increased up to $18 \mu \mathrm{g} / \mathrm{m}^{3}$ in 2006 (Maramures EPA, 1995-2006). Nevertheless, there were no exceedances throughout these years, which recorded a low annual average - it was known that the main ammonia emission source was agriculture, but the polluting gas was also released by waste platforms. Unlike 2000 , when daily MAC exceedance frequency was $5 \%$ with a daily maximum value of $284 \mu \mathrm{g} / \mathrm{m}^{3}(2,8$ times more than the MAC), between 2001 and 2006 there were no records of exceedance, with the highest daily maximum value peaking in $2005\left(98 \mu \mathrm{g} / \mathrm{m}^{3}\right)$. In 2006, the daily maximum value was $90 \mu \mathrm{g} / \mathrm{m}^{3}$, while the annual average did not go over $18 \mu \mathrm{g} / \mathrm{m}^{3}$ (Maramures EPA, 1995-2006).

\subsection{Particulate matter pollution}

In Baia Mare, for most of the analyzed timeframe, the suspended particulate matter was monitored in 3 sampling points, two of which were industrial and the third urban, as specified in subchapter 2.1. The two industrial monitoring points were located under the direct action of the emissions from the main air pollution sources in the area, Romplumb and Phoenix/Cuprom Corporations. The particulate matter analysis helped identify the metal content in the air ( $\mathrm{Pb}$ and $\mathrm{Cd})$.

Particulate matter concentrations in the Baia Mare area had an oscillating trajectory with successive increases and decreases up to 2002, while the 2002-2005 period was characterized by a downward trend followed by a slight increase in 2006 (Maramures EPA, 1995-2006), as presented in the Fig.3.

Until 2002, the particulate matter concentration values were verified using the 12574/1987 Standard, which set a daily $150 \mathrm{\mu g} / \mathrm{m}^{3}$ MAC for this indicator and an annual MAC of $75 \mu \mathrm{g} / \mathrm{m}^{3}$; these values led to exceedances of the annual MAC by $38 \mu \mathrm{g} / \mathrm{m}^{3}$. According to this standard, the maximum admissible limit was not reached in 2001 and 2002. The 592/2002 Order established a more severe particulate matter concentration limit, imposing a daily MAC of $50 \mu \mathrm{g} / \mathrm{m}^{3}$ and an annual MAC of $40 \mu \mathrm{g} / \mathrm{m}^{3}$. Between 2003 and 2006 there were constant breaches of the annual limit for this indicator; the minimum breach value was 1 
$\mu \mathrm{g} / \mathrm{m}^{3}$, in 2005 (Maramures EPA, 1995-2006).

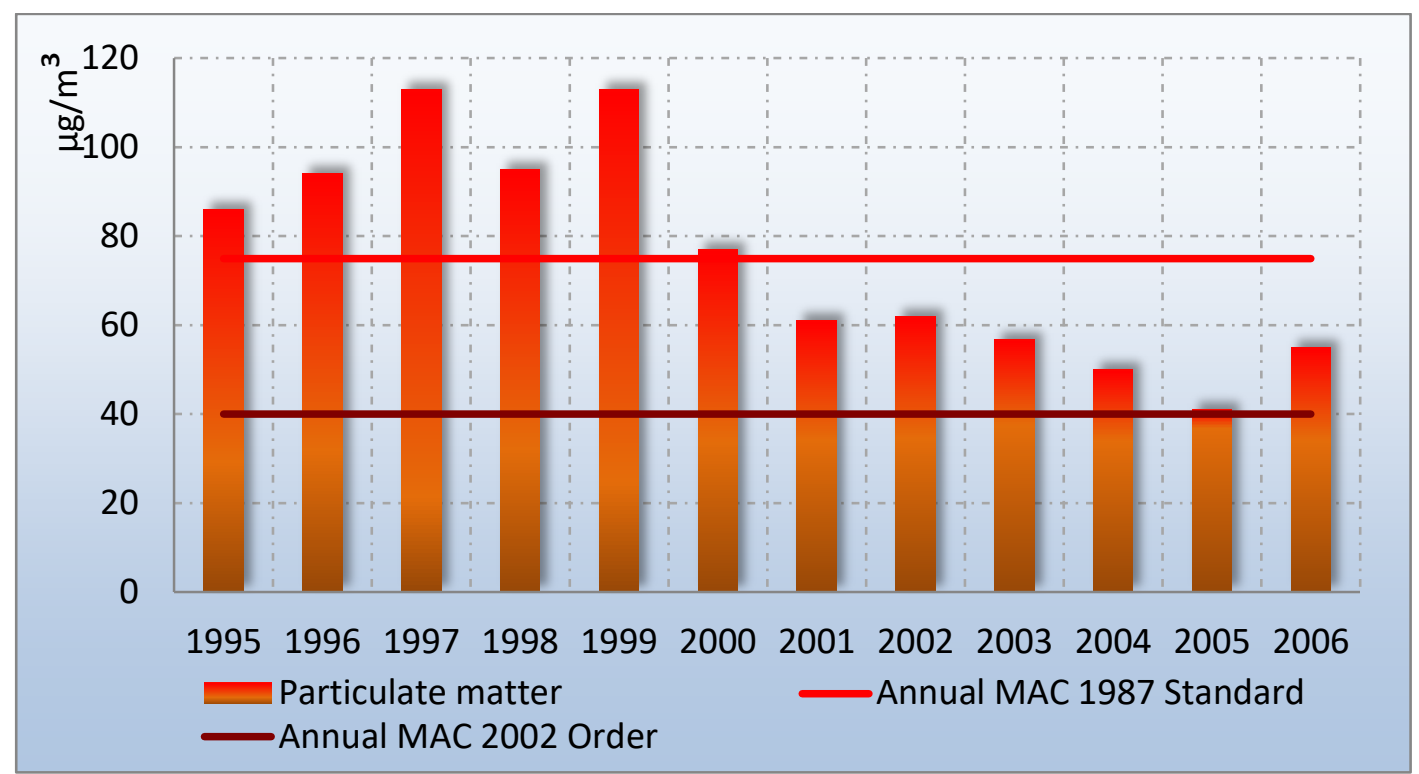

Fig. 3. The annual average values of particulate matter concentrations between 1995 and 2006

APM Maramures used the 12574/1987 Standard as a milestone in analyzing the annual frequencies of the daily MAC exceedance value. Between 1995 and 1999, both annual average values and annual exceedance frequencies of daily MAC were significant. These frequencies had values between $11 \%$ in 1995 and $21.6 \%$ in 1997 - the highest frequency for the reporting timeframe (1995-2006), followed by $21 \%$ in 1999. (Maramures EPA, 1995-2006).

Between 2000 and 2005, there was a significant decrease in both the annual average concentrations and the annual exceedance frequencies of daily MAC (Maramures EPA, 1995-2006). The largest difference was recorded between 1999 and 2000, when the annual exceedance frequency for the daily allowed value dropped from $21 \%$ to $3 \%$. In 2001 and 2002, the frequency value was under $1 \%(0.28$ and $0.73 \%$ respectively), followed by no exceedance in 2003 and 2004 according to the old 1987 Standard $\left(150 \mu \mathrm{g} / \mathrm{m}^{3}\right)$. In 2005 there were 5 exceedances of the daily MAC (according to the 12574/1987 Standard), recorded in two sampling points located near the main pollution sources (Cuprom and Romplumb Corporations). Moreover, 2005 saw the lowest annual average concentration $\left(41 \mu \mathrm{g} / \mathrm{m}^{3}\right)$ for the analyzed timeframe. In 2006, according to the 12574/1987 Standard, there were two exceedances of the daily MAC, both in the vicinity of the main pollution sources (Maramures EPA, 1995-2006).

Between 1995 and 2006, the main sources of particulate matter pollution in Baia Mare were mining and metallurgical units (Remin, Phoenix/Cuprom and Romplumb Corporations), alongside tailing dumps and ponds in the Baia Mare area; residential heating equipment and solid fuel companies; road traffic, including street dust resuspension; mixed asphalt installations; wood crafting etc. In addition to all these factors, the atmospheric calm conditions, which were unfavourable to the pollutants dispersion in the area, aggravated the effects.

\subsubsection{Heavy Metal Pollution Caused by Suspended Particulate Matter}

In Baia Mare, as it was outlined in subchapter 2.1, for most of the studied timeframe, the lead pollution level analysis was performed at 3 control points, two of which were industrial, under direct impact of pollution sources (points no. 4 and no. 16, under the influence of the Romplumb and Phoenix/Cuprom emissions), and a third located in a residential area, indirectly affected by pollution.

The evolution of lead concentrations in particulate matter between 1995 and 2006 is shown in the Fig.4.

It can be noticed that the 1995-2006 analysis interval recorded annual average concentrations of the particulate matter lead indicator well above the maximum admissible values presented in the 592/2002 Order $\left(0,5 \mu \mathrm{g} / \mathrm{m}^{3}\right)$ (Maramures EPA, 1995-2006). The daily maximum values recorded in the three monitoring points had large variations caused, on the one hand, by the operating regime and the technological dysfunctions of Romplumb Company and, on the other hand, the unfavourable weather conditions that did not allow a proper dispersion process during certain periods of time. In 2006, in the two sample collection 
points located under direct pollution source impact (sampling point no. 4 - near Romplumb Corporation; sampling point no. 16 - near Cuprom Corporation), the daily maximum values were $28.281 \mu \mathrm{g} / \mathrm{m}^{3}$ and $22.796 \mu \mathrm{g} / \mathrm{m}^{3}$, respectively. In the sampling point located in the residential area (no. 31 - Maramures EPA headquarter), the daily maximum average was $3.656 \mu \mathrm{g} / \mathrm{m}^{3}$. In 2006 , the annual average concentration for the particulate matter lead indicator was $2.025 \mu \mathrm{g} / \mathrm{m}^{3}$ (Maramures EPA, 1995-2006).

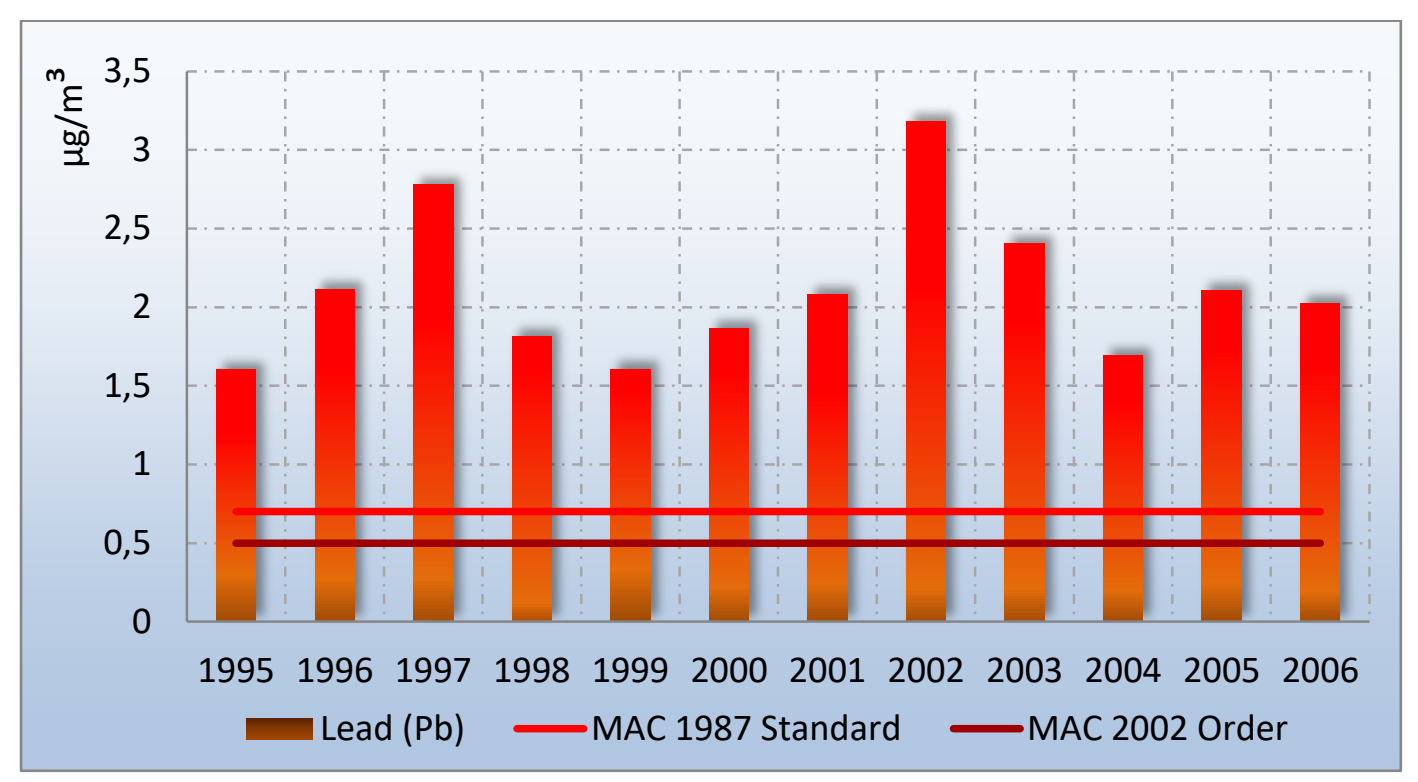

Fig.4. The evolution of lead concentrations in particulate matter between 1995 and 2006

From the comparative analysis of lead concentration levels in relation to sampling point types, it resulted that there is a significant difference between the areas found under direct impact of pollution sources and the residential area. Determining the annual exceedance frequencies for the daily MAC of the particulate matter lead indicator was done by referring to the limit value imposed by the $12574 / 1987$ Standard $\left(0,7 \mu \mathrm{g} / \mathrm{m}^{3}\right)$. The table 3 presents the values corresponding to the daily MAC exceedance frequencies between 1995 and 2006. The value for this particular indicator is not known for 1995 (Maramures EPA, 1995-2006).

Table 3. The annual exceedance frequency for the daily maximum allowable value of particulate matter lead content between 1996 and 2006 (Source: Maramures EPA, 1995-2006)

\begin{tabular}{|l|l|l|l|l|l|l|l|l|l|l|l|l|}
\hline Year & 1996 & 1997 & 1998 & 1999 & 2000 & 2001 & 2002 & 2003 & 2004 & 2005 & 2006 & $\begin{array}{l}\text { Daily } \\
\text { MAC: }\end{array}$ \\
\cline { 1 - 7 } Value $\%$ & 59,9 & 66,21 & 51 & 54 & 57 & 49 & 69 & 79 & 49 & 61 & 52 & $\begin{array}{l}0,7 \\
\mathrm{\mu g} / \mathrm{m}^{3}\end{array}$ \\
\hline
\end{tabular}

As presented above, the annual frequencies of daily MAC exceedances had oscillating occurrences, with values between 49\% (2001, 2004) and 79\% (2003) (Maramures EPA, 1995-2006).

For 2006, at the two sample collection points located near the pollution sources, the annual frequencies of daily MAC exceedances were $77 \%$ and $71.5 \%$, respectively, while at the residential sampling point the value was $8.4 \%$. In 2006, the average values for the 3 sampling points showed an annual frequency (for exceedance of the particulate matter lead indicator) of $52 \%$, lower than the year before (Maramures EPA, 1995-2006).

The cadmium pollution from particulate matter was monitored at the same collection points used for lead, while the limit value of $0.02 \mu \mathrm{g} / \mathrm{m}^{3}$ was set by the $12574 / 1987$ Standard. The annual average concentration values between 1997 and 2006 are shown in table 4. For 1995 and 1996, the annual average concentration values for cadmium are not known (Maramures EPA, 1995-2006).

The values show significant variations of the annual average concentration, a sinuous route which did not keep a steady increasing or decreasing trend. The last two analyzed years had the lowest annual cadmium concentration values. The highest value was recorded in $1997-0.027 \mu \mathrm{g} / \mathrm{m}^{3}$, while the lowest in $2005-$ $0.014 \mathrm{\mu g} / \mathrm{m}^{3}$ (Maramures EPA, 1995-2006). 
IJASOS- International E-Journal of Advances in Social Sciences, Vol. III, Issue 9, December 2017

Table 4. The annual average cadmium concentration values in particulate matter between 1997 and 2006 (Source: Maramures EPA, 1995-2006)

\begin{tabular}{|l|l|l|l|l|l|l|l|l|l|l|l|}
\hline Year & 1997 & 1998 & 1999 & 2000 & 2001 & 2002 & 2003 & 2004 & 2005 & 2006 & $\begin{array}{l}\text { Daily } \\
\text { MAC }\end{array}$ \\
\hline $\begin{array}{l}\text { Value } \\
\left(\mu \mathrm{g} / \mathrm{m}^{3}\right)\end{array}$ & 0.027 & 0.021 & 0.020 & 0.059 & 0.016 & 0.020 & 0.020 & 0.018 & 0.014 & 0.015 & 0.02 \\
\hline
\end{tabular}

In 2006, in the two sampling points located in the direct impact zone of pollution sources, the daily maximum values were 0.171 and $0.083 \mu \mathrm{g} / \mathrm{m}^{3}$, respectively. The resulting annual average values are 0.021 and 0.017 $\mathrm{\mu g} / \mathrm{m}^{3}$. For the residential area measurement point, the maximum value was $0.036 \mathrm{\mu g} / \mathrm{m}^{3}$, significantly lower than the other two sampling points, with an annual average of $0.007 \mu \mathrm{g} / \mathrm{m}^{3}$. Overall, in 2006 , the cadmium indicator annual average for the three sampling points was $0.015 \mu \mathrm{g} / \mathrm{m}^{3}$, higher than in 2005 , but lower than in the previous monitored years (Maramures EPA, 1995-2006).

The annual exceedance frequencies of the daily MAC are presented in the table 5.

Table 5. The annual exceedance frequency of the daily maximum admissible value for cadmium in particulate matter between 1995 and 2006 (Source: Maramures EPA, 1995-2006)

\begin{tabular}{|c|c|c|c|c|c|c|c|c|c|c|c|c|}
\hline Year & 1996 & 1997 & 1998 & 1999 & 2000 & 2001 & 2002 & 2003 & 2004 & 2005 & 2006 & Daily \\
\hline $\begin{array}{l}\text { Value } \\
(\%)\end{array}$ & 28.88 & 36.26 & 32 & 29.5 & 32.1 & 25 & 27.8 & 33.3 & 26.8 & 24.3 & 22.7 & $\begin{array}{l}0.02 \\
\mu \mathrm{g} / \mathrm{m}^{3}\end{array}$ \\
\hline
\end{tabular}

The annual exceedance frequencies oscillated between a minimum of $22.7 \%$ in 2006 and a maximum of $36.26 \%$ in 1997 . For the analyzed timeframe, the daily maximum concentrations ranged between 0.086 $\mu \mathrm{g} / \mathrm{m}^{3}$ in 2005 and $1.640 \mu \mathrm{g} / \mathrm{m}^{3}$ in 1995. In 2006, the evolution of the particulate matter cadmium concentrations appeared to generally maintain the same trends as lead, both in terms of concentrations and exceedance frequencies, but at lower levels. Therefore, for the two sampling points located in the industrial area, the annual exceedance frequency was of $35.5 \%$ and $30.7 \%$, respectively, while at the no. 31 measuring point (Maramures EPA headquarter), there was a $2 \%$ frequency, leading to an overall average of 22.7\% (Maramures EPA, 1995-2006).

During the analyzed period, the main sources of heavy metal pollution were the mining and metallurgical units (Remin, Cuprom/Phoenix and Romplumb Corporations), the tailing dumps and tailing ponds in the Baia Mare area (with the air currents engaging the heavy metal-rich particulate matter), but also road traffic, including the road dust resuspension, as lead gasoline was still widely used during those years. Another important factor consisted of meteorological conditions, as the atmospheric calm was unfavourable to pollution dispersion in the Baia Mare area.

\subsection{Sedimentary Matter Pollution}

The sedimentary matter was monitored in 7 points in the Baia Mare area. The annual values recorded between 1998 and 2003 are presented in Table 6.

Table 6. The annual values of sedimentary matter between 1998 and 2003 (Source: Maramures EPA, 19952006)

\begin{tabular}{|l|l|l|l|l|l|l|l|}
\hline Year & 1998 & 1999 & 2000 & 2001 & 2002 & $\mathbf{2 0 0 3}$ & MAC \\
\hline Value $\left(\mathrm{t} / \mathrm{km}^{2} /\right.$ year $)$ & 41.690 & 44.089 & 44.657 & 51.259 & 51.819 & 57.975 & 200 \\
\hline
\end{tabular}

The annual values of sedimentary matter ranged between $41.690 \mathrm{t} / \mathrm{km}^{2} / \mathrm{year}$ (first analysed year) and 57.975 $\mathrm{t} / \mathrm{km}^{2} /$ year (last analysed year), without exceeding the annual limit of $200 \mathrm{t} / \mathrm{km}^{2} /$ year set by the $12574 / 1987$ Standard.

Evolutionally, the annual amount of the sedimentary matter indicator recorded a steady increase over the years. The APM Maramures report contains information on sedimentary matter for 2004 as well, but the annual value is not specified, informing only on the fact that the quantitative values range from 23.4 $\mathrm{t} / \mathrm{km}^{2} /$ year to $145 \mathrm{t} / \mathrm{km}^{2} /$ year, exceeding the monthly limit of $17 \mathrm{~g} / \mathrm{m}^{2} /$ month (12574/1987 Standard) only twice 
and without reaching the annual average concentration limit (Maramures EPA, 1995-2006). The analysis of sedimentary matter helped identify the metal content $(\mathrm{Pb}, \mathrm{Cd}$ and $\mathrm{Cu})$, and the influence of the local pollution sources was highlighted by the significantly higher values recorded in the Baia Mare area. The table 7 clearly shows the minimum monthly values of the lead indicator going down to zero from 2001 to 2004, while the maximum values went down by $35 \mathrm{mg} / \mathrm{m}^{2} / \mathrm{month}$ (Maramures EPA, 1995-2006).

Table 7. The heavy metal content in sedimentary matter between 2001 and 2004 in the Baia Mare area (Source: Maramures EPA, 1995-2006)

\begin{tabular}{|c|c|c|c|c|c|c|}
\hline Year & $\begin{array}{c}\text { Minimum Pb } \\
\left(\mathbf{m g} / \mathbf{m}^{2} /\right. \\
\mathbf{m o n t h})\end{array}$ & $\begin{array}{c}\text { Maximum } \\
\mathbf{P b}\left(\mathbf{m g} / \mathbf{m}^{2} /\right. \\
\mathbf{m o n t h})\end{array}$ & $\begin{array}{c}\text { Minimum Cd } \\
\mathbf{( m g / \mathbf { m } ^ { 2 } /} \\
\mathbf{m o n t h})\end{array}$ & $\begin{array}{c}\text { Maximum } \\
\mathbf{C d}\left(\mathbf{m g} / \mathbf{m}^{2} /\right. \\
\mathbf{m o n t h})\end{array}$ & $\begin{array}{c}\text { Minimum } \mathbf{C u} \\
\left(\mathbf{m g} / \mathbf{m}^{2} /\right. \\
\mathbf{m o n t h})\end{array}$ & $\begin{array}{c}\text { Maximum } \\
\mathbf{C u}\left(\mathbf{m g} / \mathbf{m}^{2} /\right. \\
\mathbf{m o n t h})\end{array}$ \\
\hline 2001 & 4.896 & 76.626 & 0.061 & 3.005 & 1.386 & 177.487 \\
\hline 2003 & 1.333 & 49.946 & 0.0 & 3.054 & 0.081 & 256.963 \\
\hline 2004 & 0.0 & 41.698 & 0.0 & 2.443 & 0.022 & 168.509 \\
\hline
\end{tabular}

Regarding the presence of cadmium in sedimentary matter, between 2001 and 2004 the minimum values decreased until they reached zero and, although 2003 shows a higher maximum value than the previous year, the value's subsequent trend was decreasing. Regarding the copper content, in the Baia Mare area the minimum value decreased, while the maximum value of 2004 was slightly lower than 2001 , and reached its peak maximum value for the analyzed timeframe in 2003 (Maramures EPA, 1995-2006).

The main pollution sources with sedimentary matter containing heavy metals were the same found for heavy metal-containing particulate matter. These sources were presented in subchapter 2.4 .

\section{CONCLUSIONS}

In Baia Mare, known as an old mining and metallurgical centre, the historical environmental pollution (including air pollution) was caused by 3 main sources: the National Company of Precious and Nonferrous Metals (NCPNM) - Remin Corporation; Cuprom Corporation; Romplumb Corporation.

As a conclusion to the measurements listed above, air quality in Baia Mare between 1995 and 2006 was strongly affected by high concentrations of particulate matter with high lead and cadmium content, alongside high concentrations of sulphur dioxide between 1995 and 2000. These pollutants were generated by the local mining and metallurgical units (Remin, Phoenix/Cuprom and Romplumb Corporations), as well as: tailing dumps and tailing ponds in the Baia Mare area, through particulate matter dispersion by air currents; residential heating equipment and solid fuel companies; road traffic, including resuspension of road dust; asphalt mixture installations, wood crafting etc. Another contributor to the deterioration of air quality was the atmospheric calm, unfavourable to pollution dispersion in the area. Romplumb Corporation (non-ferrous metallurgy unit: the production of decopperised lead) generated emissions with high concentrations of lead and cadmium, which were recorded in more than three quarters of the year 2006. Until 2000, when the main technological processes were interrupted, air quality was significantly affected by the emissions generated by Cuprom Corporation (formerly known as Phoenix), with a non-ferrous metallurgy profile (primarily copper and sulphuric acid production). Since 2000, Romplumb Corporation was the source that led to the high levels of lead and cadmium, as well as $\mathrm{SO}_{2}$, which frequently exceeded limit values.

However, in the analyzed timeframe, the overall pollutant concentration trend in the Baia Mare area was decreasing, both for heavy metals and $\mathrm{SO}_{2}$, which was a result of the decline in the activity of local polluters. The investments made in technological upgrades did not determine significant changes in urban air quality improvement. Romplumb and Cuprom Corporations introduced pollutant dispersion chimneys equipped with automated monitoring and online transmission systems for data recording at Maramures EPA. Currently, Remin and Romplumb Corporations are insolvent and Cuprom Corporation is bankrupt. 


\section{REFERENCE LIST}

Manoiu V.-M, Spiridon R.-M (2017), A Deep Dive into the Chronic Air Pollution Reality in Baia Mare. Part I: Sources of Historical Environmental Pollution in Baia Mare and their Contribution to Air Pollution. Submitted for publication.

Maramures Environmental Protection Agency/Agentia pentru Protectia Mediului Maramures (1995-2006), Annual Reports on Maramures County Environmental State/Rapoarte anuale privind starea mediului in judetul Maramures, http://www.anpm.ro/web/apm-maramures/rapoarte-anuale1

National Institute of Statistics/Institutul National de Statistica, 2011 Census Results/Rezultate recensamant 2011, http://www.recensamantromania.ro/rezultate-2/ 